\title{
ISOLATION OF CHROMOBACTERIUM PRODIGIOSUM FROM EMPYEMA
}

\author{
BY \\ JOHN PAPAPANAGIOTOU AND CH. ALIGIZAKIS* \\ From the Department of Bacteriology, Greek Seamen's Chest Hospital, and the Surgical Clinic, \\ Sanatorium "Penteli," Melissia, Athens
}

(RECEIVED FOR PUBLICATION JULY 17, 1958)

\begin{abstract}
Chromobacterium prodigiosum (Serratia marcencens) is an aerobic, motile, Gram-negative rod that produces a red pigment which is insoluble in water. This bacterium has generally been considered to be a saprophyte. It is usually found in water and soil and may contaminate food.
\end{abstract}

There are, however, in the literature reports of cases where Chr. prodigiosum has been isolated from pathological processes in men and animals. Patterson, Banister, and Knight (1952) have described a fatal septicaemia, Aronson and Alderman (1943) and Rabinowitz and Schiffrin (1952) meningitis, Hawe and Hughes (1954) bacterial endocarditis, and Wheat, Zuckerman, and Rantz (1951) reported 11 cases of urinary tract infections due to Chr. prodigiosum. In 1913 Woodward and Clarke reported a case of a patient who had a chronic cough, probably from bronchiectasis. $\mathrm{He}$ brought up "bloody" sputum, but red blood cells were not found in the sputum. Cultures of the sputum grew Chr. prodigiosum. It seems obvious that the red colour of the sputum was due to the red pigment of the organism. Robinson and Woolley (1957) and Gale and Lord (1957) reported similar cases. Also Déom and Mortelmans (1953) described a fatal infection with $\mathrm{Chr}$. prodigiosum in a colt.

\section{Case Report}

A man, aged 55, was admitted to hospital in February, 1957, with right spontaneous pneumothorax. In 1948 this patient had had a left spontaneous pneumothorax. With continuous suction the lung re-expanded in 24 hours, confirmed radiologically. Two days later fluid was present in the right costophrenic angle and the lung collapsed. The fluid was aspirated but not cultured. Thoracoscopy was performed on April 3, 1957. On April 25 the patient was admitted to the surgical clinic with extreme dyspnoea. Intercostal drainage was established with

\footnotetext{
*Present address: "Sismanoglion" Chest Hospital, Athens,
}

continuous suction. On May 7 "blood-stained" fluid drained through the tube, and the patient started to have pyrexia up to $38.5^{\circ} \mathrm{C}$. The fluid was not cultured. To secure a better dependent drainage of the chest, a self-retaining catheter was introduced into the sixth intercostal space anterially. The "bloodstained" fluid draining from this catheter was cultured on May 28 and Chr. prodigiosum in pure culture was isolated. Two further cultures on June 8 and July 1 yielded Chr. prodigiosum and a few colonies of Pseudomonas aeruginosa.

On June 10 chlortetracycline, 1.5 g. per day, was begun orally, but the temperature remained high. Following a sensitivity test chloramphenicol was instilled into the pleural cavity. The temperature gradually fell and the lung started to re-expand. By August the lung had re-expanded, but a small empyema cavity remained at the right base. Cultures on August 8 and September 14 yielded Pseudomonas aeruginosa.

\section{Bacteriology}

The organism isolated was a Gram-negative, motile, short rod with occasional longer rods. It formed round, convex colonies with a smooth, shiny surface on nutrient agar and blood-agar plates. It grew at $37^{\circ} \mathrm{C}$. as well as at $25^{\circ} \mathrm{C}$. It produced orange-red pigment on agar at $25^{\circ} \mathrm{C}$., which deepened after three to four days, but at $37^{\circ}$ C. gave little or no pigment. The red pigment was insoluble in water, but soluble in alcohol and in chloroform. An alcoholic solution of the pigment turned bright pink on the addition of hydrochloric acid and yellow on the addition of alkali. On blood-agar pigment was produced at $25^{\circ}$ C. and there was haemolysis. The organism grew on MacConkey medium, but the colonies were smaller and produced deep red pigment on standing at room temperature. It produced dense turbidity in broth at $25^{\circ} \mathrm{C}$., with a pink ring. It produced clot in litmus milk, followed by liquefaction. Saccate liquefaction was caused in a gelatin stab and a deep red 
pigment produced. The organism liquefied Löwenstein-Jensen and Loeffler's media. Other reactions were as follows: Indole -, M.R. -, VP +, Koser's citrate + , nitrates reduced to nitrites; $\mathrm{NH}_{3}$ production + , catalase + , methylene blue reduced, urea - at $24 \mathrm{hr}$., $\mathrm{H}_{2} \mathrm{~S}$ (on Kligler's medium) -, phenyl-pyruvic acid (Henriksen), K.C.N. (Möller test) +, malonate -, amino-acid decarboxylases; lysine + , ornithine + , glutamic acid - , arginine - . It produced acid and a little gas from glucose, maltose, sucrose, mannitol, and salicin at $37^{\circ} \mathrm{C}$., but not from lactose, dulcitol, or xylose.

The description of this organism resembles that of Chromobacterium prodigiosum given by Wilson and Miles (1955).

Sensitivity to Antibiotics.-The isolated strain was sensitive by the paper disc method to streptomycin, chloramphenicol, and neomycin, and resistant to penicillin, oxytetracycline, chlortetracycline, tetracycline, and erythromycin.

Pathogenicity for White Mice. - The pathogenicity of the isolated organism for mice was determined as follows:

Groups of five mice were injected intraperitoneally with $0.2 \mathrm{ml}$., $0.1 \mathrm{ml}$., or $0.05 \mathrm{ml}$. of a 24-hour broth culture. All five died after $0.2 \mathrm{ml}$., three after $0.1 \mathrm{ml}$., and one after $0.05 \mathrm{ml}$. All mice survived injection of $0.2 \mathrm{ml}$. of a 1 in 10 dilution of a 24-hour broth culture. Five mice were injected with $0.05 \mathrm{ml}$. of the 24-hour broth culture. At 24 hours only one mouse was dead. The other mice survived. Four groups of four mice each were inoculated with $0.2 \mathrm{ml}$. of serial dilutions $\left(10^{-1}\right.$ to $\left.10^{-4}\right)$ in peptone water of the above 24-hour broth culture. All the mice survived. The number of viable organisms inoculated was counted by the method of Miles and Misra (1938) and the lethal dose of this organism for mice was estimated to be $>11,000,000$ bacteria.

\section{Discussion}

In the textbooks of bacteriology Chr. prodigiosum has been described as a saprophyte. But there seems to be little doubt, from the published reports, that this organism can produce mild or fulminating fatal illness. Gale and Lord (1957) observed in mice enhancement of the virulence of a strain of Chr. prodigiosum when injected with mucin. It has been noted by many workers that the virulence of an organism will be enhanced by mucin only if the organism is pathogenic or at least weakly pathogenic.

In the present case the same organism, Chr. prodigiosum, was isolated three times over a period of 30 days. In the first culture (May 29) of the empyema fluid, Chr. prodigiosum was isolated in pure culture. In the other cultures (June 8 and July 1) a few colonies of Pseudomonas aeruginosa were isolated in addition to the profuse culture of Chr. prodigiosum. It is difficult, therefore, to assess with certainty the pathogenicity of $\mathrm{Chr}$. prodigiosum. However, the isolated strain was weakly pathogenic for mice. Moreover, the development of the infection suggests strongly the pathogenicity of the organism, while the subsidence of the fever was accompanied by disappearance of $\mathrm{Chr}$. prodigiosum but not of the Ps. aeruginosa.

The beneficial therapeutic result following the instillation of chloramphenicol into the pleural cavity should be noted. This observation is in accordance with the antibiotic sensitivity test in vitro. Robinson and Woolley (1957) and Béguet (1953) reported the sensitivity in vitro to chloramphenicol of Chr. prodigiosum. Also Hawe and Hughes (1954) thought that either chloramphenicol or neomycin might offer the best chance of successful treatment.

\section{Summary}

The isolation of a strain of Chr. prodigiosum from empyema fluid is presented. A description of this strain is given.

We wish to thank Dr. M. T. Parker, of the Public Health Laboratory, Manchester, who confirmed the identity of the strain of Chr. prodigiosum and kindly performed the amino-acid decarboxylases, K.C.N., P.P.A., and malonate tests.

\section{REFERENCES}

Aronson, J. D., and Alderman, I. (1943). J. Bact., 46, 261. Béguet, M. (1953). Ann. Inst. Pasteur, 85, 394.

Déom, J., and Mortelmans, J. (1953). Rev. Immunol. (Paris), 17, 394.

Gale, D., and Lord, J. D. (1957). J. Amer. med. Ass., 164, 1328.

Hawe, A. J., and Hughes, M. H. (1954). Brit. med. J., 1, 968.

Miles, A. A., and Misra, S. S. (1938). J. Hyg. (Camb.), 38, 732.

Patterson, R. H., Jr., Banister, G. B., and Knight, V. (1952). Arch. intern. Med., 90, 79.

Rabinowitz, K., and Schiffrin, R. (1952). Harefuah, 42, 90.

Robinson, W., and Woolley, P. B. (1957). Lancet, 1, 819.

Wheat, R. P., Zuckerman, A., and Rantz, L. A. (1951). Arch. intern. Med., 88, 461.

Wilson, G.S., and Miles, A. A. (1955). Topley and Wilson's Principles of Bacteriology and Immunity, 4th ed. Arnold, London.

Woodward, H. M. M. , and Clarke, K. B. (1913). Lancet, 1, 314. 